\title{
Motor Development in Malnourished Children in Indonesia
}

\author{
Yasuhide Nakamura," Masroel Siregar**
}

\begin{abstract}
*Department of Community Health, School of International Health, The University of Tokyo, ${ }^{* \star}$ North Sumatera Health Office, the Ministry of Health, Indonesia
\end{abstract}

\begin{abstract}
Severe protein-energy malnutrition during infancy is closely related to physical growth and mental development. Very lew reports mention the effects on motor development of mildly to moderately malnourished infants. Our study was conducted to clarify the relationship between malnutrition and motor development during infancy. We examined 1,065 children at Posyandu (Intregated Services Posts) in North Sumatera, Indonesia. Motor development, such as sitting and walking, was significantly more delayed in malnourished children than in well-nourished children. Parachute reaction showed no significant differences between well-nourished and malnourished children. Parachute reaction is a very simple technique and can differentiate between children with cerebral-palsy and malnourished children unable to walk. It might be one of the most appropriate technologies for use at the primary care level. [Paediatr Indones 1998; 38:29-37]
\end{abstract}

\section{Introduction}

Severe protein-energy malnutrition during infancy is closely related to physical growth and mental development. Severe malnutrition has detrimental effects on mental, behavioral and cognitive development of children despite the influences of the social and cultural deprivation. ${ }^{1-6}$ The effects, however, of mild to moderate malnutrition on children's development are less clear. The effects of malnutrition on mental and behavioral development during infancy are markedly influenced by the social and economic backgrounds of families with malnourished children. It is difficult to differentiate the effects of mild to moderate malnutrition from the effects of environmental factors in any single study. Lloyd-Still et al said that ever severely malnourished infants could 
catch up after 5 years of age when socioeconomic conditions were improved. ${ }^{7}$ Some studies showed no difference in the cognitive development of malnourished and betterfed siblings ${ }^{8}$ and in the cognition after control of variables for socioeconomic status. ${ }^{9}$ However, other studies showed mild to moderate malnutrition affected the child's development adversely even when other environmental characteristics were considered. ${ }^{10}$

Very few reports mentioned the effects on motor development of mildly to moderately malnourished infants. Super mentioned that guardians in Kenya encourage their children to sit, stand and walk, and paid little attention to crawling and turning over. ${ }^{11}$ Children aged 4 to 6 years in the Philippines with a documented history of malnutrition showed lower motor and perceptual skill scores than their normal counterparts. ${ }^{12}$ Among Senegalese children between the ages of 10 and 13 years, mal-nourished children presented poorer functional performances than well-nourished children. ${ }^{13}$ Only a few reports, however, have mentioned the neurological responses of malnourished children during infancy and early childhood. An appropriate indicator of neurological responses is the parachute reaction: when an infant in prone position is suddenly lowered towards a flat surface, the arms extend forward and the hands open. ${ }^{14}$ Parachute reactions are seen in neurologically normal infants aged 6 to 12 months. There are no reports on parachute reaction in malnourished children.

The objectives of this study were to clarify the relationship between malnutrition and motor development during infancy and to investigate the implications of parachute reaction in malnourished and well-nourished infants.

\section{Methods}

Chidren younger than 5 years of age were examined in Posyandu in Asahan Regency, North Sumatra Province, Indonesia. This area had about 830,000 population with $4,681 \mathrm{~km}^{2}$. Java, Batak, and Melayu tribes composed $45 \%, 28 \%$ and $22 \%$ of the population respectively. The study was conducted from January 1987 to September 1987 in 42 Posyandu in 11 villages in Asahan Regency, and 1,065 children who attended Posyandu were examined for body weight, motor development and parachute reaction. Posyandu, established by the Government of Indonesia in 1985, holds community activities every month at the village level to promote maternal and child health, family planning, nutrition, immunization, and diarthea control through community participations.$^{15}$ In Posyandu, registration, body weighing, recording, and consultation are usually implemented by village health volunteers and health center staff.

In this study, one of the pediatrician authors (YN) examined all the children who attended to Posyandu. No treatment, however, was given in Posyandu to children who needed medicine. The children were referred to a neighboring health center, in accordance with national policy of the patient referral system. 
Body weight of the children was measured with standardized beam balance by village health volunteers. According to Harvard Standard Line (50 percentile of Harvard Standard), the children were categorized into good nutritional status ( $80 \%$ and over of Harvard Standard Line) and malnutrition (less than $80 \%$ of Harvard Standard Line). Anthropometric measurements including height-for-age and height-for-weight were desirable. ${ }^{16}$ We could not measure height, because of a lack of field-workers able to measure height, and this study should follow a national standard that is a classification of weight-for-age by Harvard Standard Line. For screening malnourished children in the community, weight-for-height is the best method but weight-for- age is the simplest method for monitoring growth of children. ${ }^{17}$ The age of a child was recorded by statement of parents or guardians. When parents forgot the accurate date, a date of birth was estimated with the local calendar.

Children under 20 months of age were examined with regard to motor development and parachute reaction by one of the authors (YN) from the viewpoint of a neuropediatrician. In this study, sitting without support means that a child can sit free for more than 30 seconds, and walking means that a child can walk without any support for a couples of paces. A positive parachute reaction means that when a child in prone position is lowered suddenly toward a flat surface, the arms extend forward and the hands open. ${ }^{14}$

The chi-square test was used to check association between variables, and Fisher's exact test was used in place of the chi-square test when any of the expected values were less than five.

\section{Results}

Among 1,065 children examined in the study, children younger than the age of 2 years were $64.2 \%$, and the number of examined children was decreased by age (Table 1). In the study areas, we could not get accurate coverage because of lack of health information on the number of newhoms and age-specific populations. We estimated the coverage to be about $80 \%$ in 11 villeses, utilizing the total population of villages and the crude birth rate of North Sumatra Province.

The average body weight of the infants younger than 6 months matched the Harvard Standard Line but weight gain diminished between the ages of 6 and 12 months. After 1 year of age, the average curve of body weight followed $80 \%$ of the Harvard Standard Line and did not catch up to the Standard Line (Figure 1).

Two hundred four infants aged 6 to 12 months were examined for sitting ability. At 8 months of age, $79 \%$ of well-nourished infants could sit without support, while only $38 \%$ of malnourished infants could sit (Figure 2). Sitting without support was significantly delayed in malnourished 8-month-old infants ( $\mathrm{p}<0.05)$. For walking ability, 293 children aged 9 to 20 months were examined. From 15 to 16 months of age, $89 \%$ 
Table 1. Children examined by age in Posyandu

\begin{tabular}{|c|c|c|}
\hline Age of months & Number of children & 2\% \\
\hline $0-5$ & 163 & 15.3 \\
\hline $6-11$ & 227 & 21.3 \\
\hline $12-17$ & 166 & 15.6 \\
\hline $18-23$ & 128 & 12.0 \\
\hline $24-29$ & 101 & 9.5 \\
\hline $30-35$ & 92 & 8.6 \\
\hline $36-41$ & 79 & 7.4 \\
\hline $42-47$ & 45 & 4.2 \\
\hline $48-53$ & 37 & 3.5 \\
\hline $54-60$ & 27 & 2.5 \\
\hline TOTAL. & 1.065 & 1000 \\
\hline
\end{tabular}

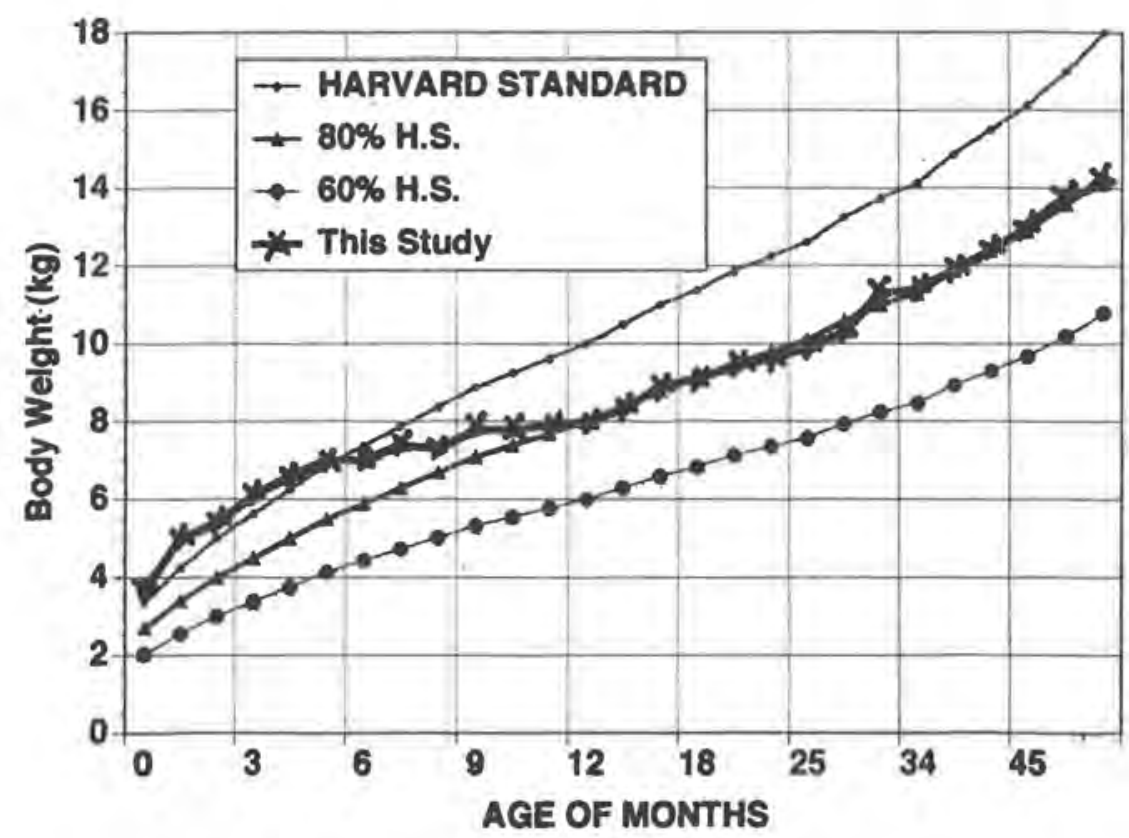

Fig 1. Body weight curve (Posyandu Survey, 1987) $(\mathrm{N}=1065)$ 


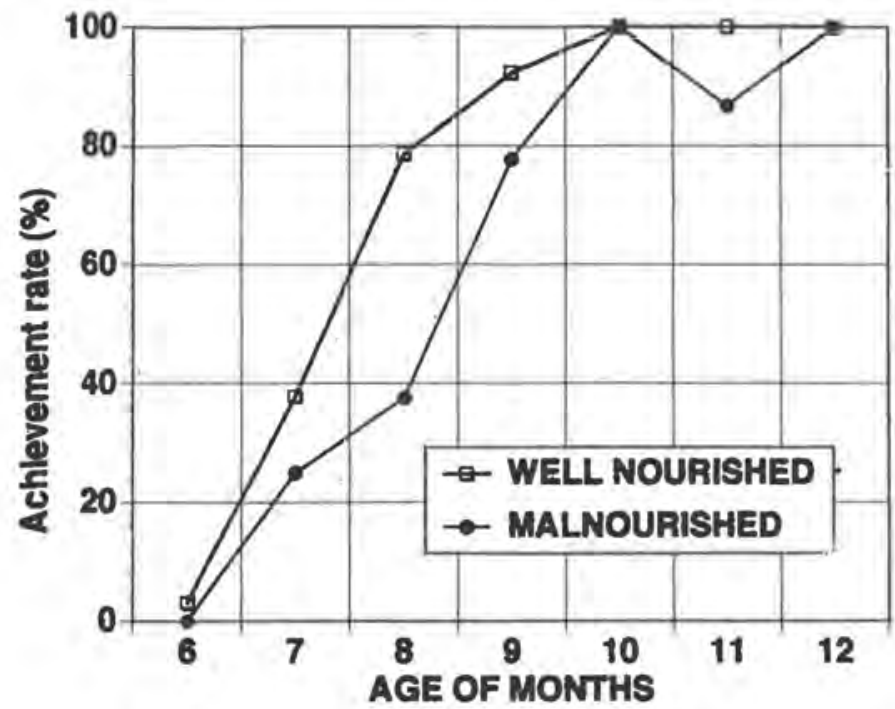

Fig 2. Sitting without support (Posyandu Survey, 1987) ( $N=204$ )

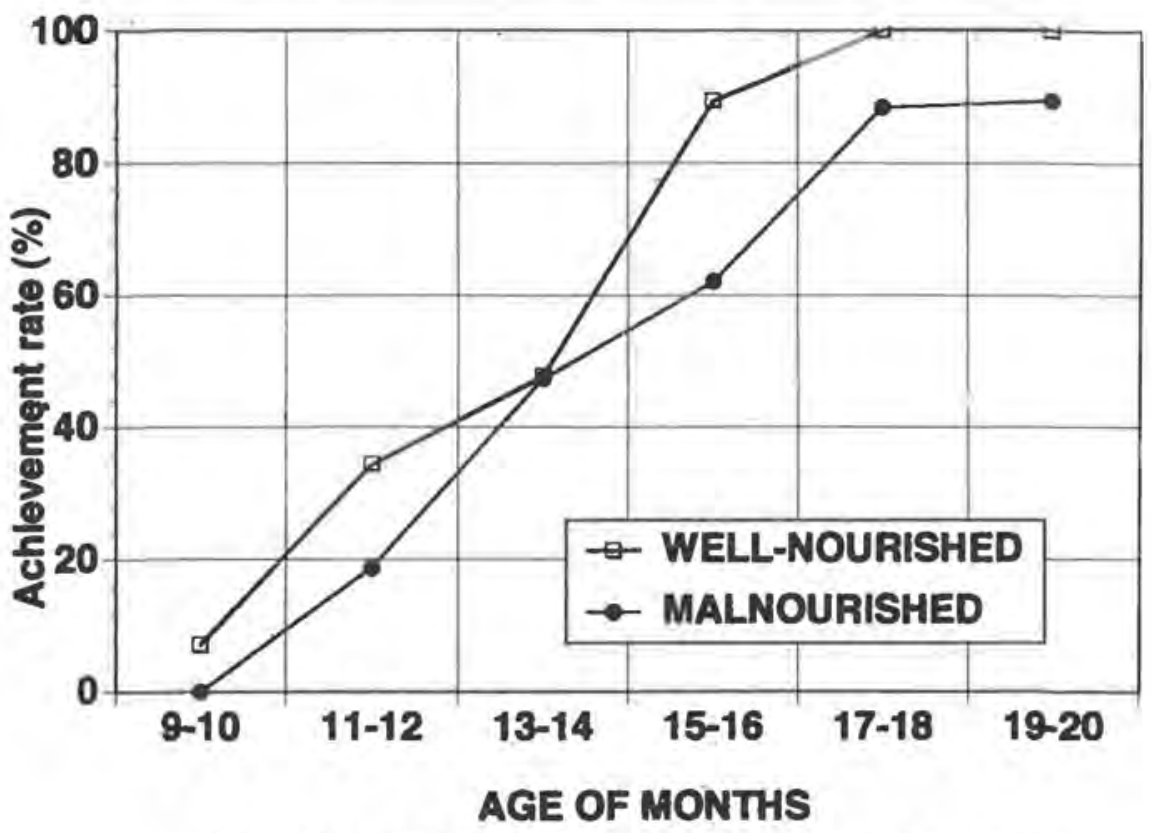

Flg 3. Walking without support (Posyandu Survey, 1987) ( $\mathrm{N}=293$ ) 


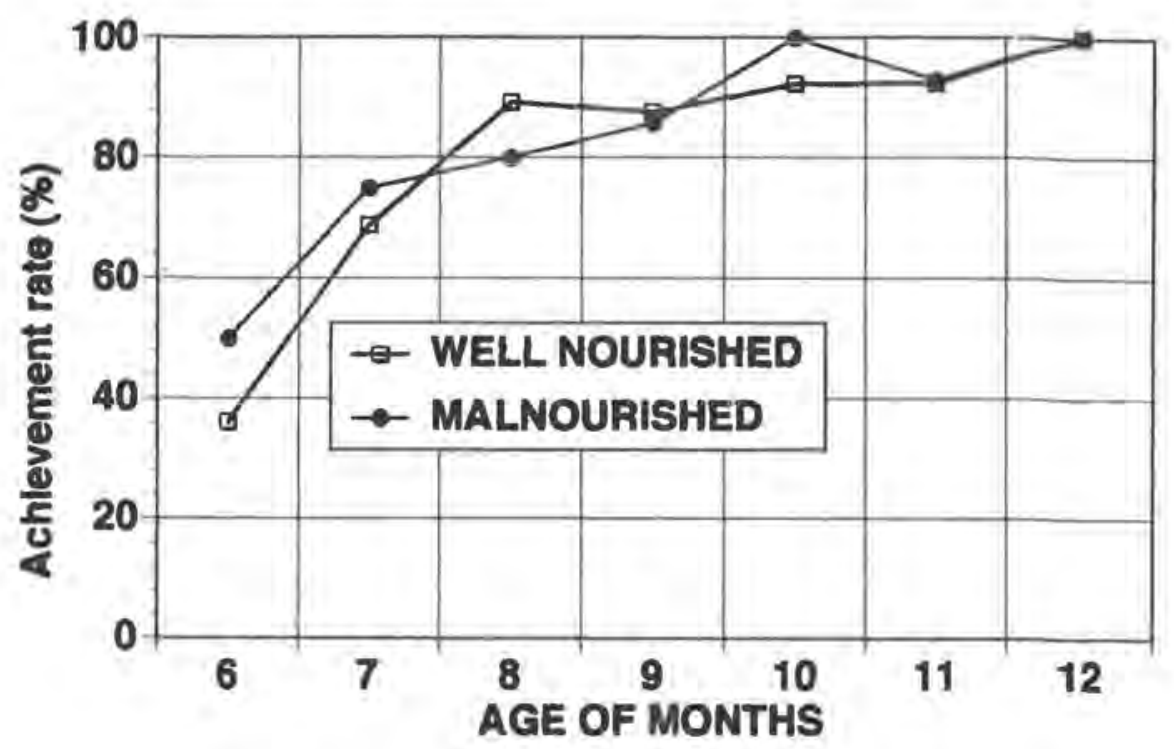

Fig 4. Parachute reaction (Posyandu Survey, 1987) $(N=177)$

of well-nourished children could walk without support, while only $62 \%$ of mal- nourished children could walk (Figure 3). Walking without support was significantly delayed in malnourished children aged 9 to 20 months $(p<0.05)$. All of the well-nourished children aged 17 months or older, 5 children could not walk due to malnutrition. As for parachute reaction, 177 infants aged 6 to 12 months were examined. Most of the children older 9 months demonstrated parachute reaction. There were no statistically significant differences between well-nourished and malnourished infants (Figure 4).

\section{Discussion}

In this study, motor development, such as sitting and walking, was delayed significantly more in malnourished children than in well-nourished children. Parachute reaction, a neurological response, showed no significant difference between well-nourished and malnourished children.

It is well known that severe malnutrition causes infants to be unable to maintain sitting or standing positions because of severe muscle weakness. ${ }^{18}$ There have been no reports on the achievement rate of motor development of infants and young children in Indonesia: neither well-nourished nor malnourished. It was very difficult to assess 
normal notor development in Indonesia because developmental and behavioral problems are influenced by the culture, including the effects of parent sensitivities and various living environtments. ${ }^{19}$ The results of this study, however, suggest that the achievement of sitting and walking of well-nourished children might be considered a milestone of motor development in Indonesian children.

Parachute reaction is considered a postural brainstem reflex. In, Japan, parachute reaction is commonly used as a check up technique in well-baby clinics. Parachute reaction is usually seen in infants aged 6 to 9 months. When a child older than 12 months doesn't show parachute reaction, cerebral palsy or other neurological disorders are suspected. In this study, we saw no significant differences between wellnourished and malnourished children, and most of children older than 9 months showed parachute reaction. These findings suggest that neurological development in brainstem seems to be intact in mildly and moderately malnourished children and their delayed motor development may be due to weakness of anti-gravity muscles.

Following the study, we visited Posyandu more than one hundred times and found that for almost all of the-2-year-old children unable to walk the parents or guardians were advised to improve the nutritional condition by health center staff, and were not checked by neurological examinations. When the malnutrition rate was extremely high, the proportion of cerebral palsy or other neurological disorders among children unable to walk was relatively low and neurological investigation had a low priority. Nutrition, however is markedly improved because health promotion activities are successful and community awareness of nutritional improvement has been strengthened. The proportion of children with cerebral palsy or other neurological disorders might be increasing among children who show delayed motor development. Therefore, differential diagnosis between malnutrition and cerebral palsy has a higher priority than before.

There are very few specialists for child neurology in many developing countries. It is very difficult for local health workers to differentiate between malnutrition and cerebral palsy. Parachute reaction is a very simple technique and can demonstrate the difference: positive parachute reaction in malnourished children unable to walk vs no parachute reaction in children with ces.bral palsy. Parachute reaction alone can not completely differentiate between malnutriuon and cerebral palsy, but parachute reaction may be used to distinguish neurologicel disorders from malnourished children unable to walk. Parachute reaction might be cne of the most appropriate methods in the primary care where few specialists are stationed and many health workers are keen toward malnutrition.

\section{Acknowledgments}

The project was supported by the North Sumatra Health Promotion Project between the Government of Indonesia and the Japan International Cooperation Agency (JICA). 
We thank the Ministry of Health, the Govemment of Indonesia, for permitting us to carry out the study. We acknowledge all health center staff and village health volunteers in Asahan Regency of North Sumatera for carrying out the investigations.

\section{References}

1. Cravioto J, De Licardie ER, Birch HG. Nutrition, growth and neurointegrative development. Pediatrics 1966; 38:319-33.

2. Chase HP, Martin HP. Undernutrition and child development: New Engl J Med 1970; 282:933-9.

3. Stein Z, Susser M, Saenger G, Marolla F. Nutrition and mental performance. Science $1972 ; 178: 708-13$.

4. Galler JR, Ramsey FC, Salt P, Archer E. Long-term effects of early Kwashiorkor compared with marasmus. J Pediatr Gastroenterol Nutr 1987; 6:841-6.

5. Winick M, Meyer KK, Harris RC. Malnutrition and environmental enrichment by early adoption. Science 1975; 190:1173-5.

6. Beardslee WR, Wolf PH, Hurwitz I, Parikh B, Shwachman H. The effects of infantile malnutrition on behavioral development, Am J Clin Nutr 1982; 35;1437-41.

7. Lloyd-still JD, Hurwitz I, Wolff PH, Shwachman H. Intellectual development after severe malnutrition during an infancy. Pediatries 1974; 54:306-11.

8. Evans DE, Moodie AD, Hansen JDL, Kwashiorokor and intellectual development. S Afr Med J 1971; 45:1413-26.

9. Bogin B, Mac Vean RB. The relationship of socioeconomic status and sex to body size, skeletal maturation, and cognitive status of Guatemala City Schoolchildren. Child Dev $1983 ; 54: 115-28$.

10. Sigman M, Neumann C, Baksh M, Bwibo N, Mc Donald MA. Relationship between nutrition and development in Kenyan toddlers. J Pediatr 1989; 115:357-64.

11. Super CM. Environmental effects on motor development. Dev Med Child Neurol 1976; 18:561-7.

12. Reyes MR, Valdecanas CM, Reyes OL, Reyes TM. The effects of malnutrition on the motor, perceptual, and cognitive functions of Filipino Children. Int Disabil Stud 1990; 12:131-6.

13. Benefice $E$. Physical activity and anthropometric and functional characteristics of mildly malnourished Senegalese children. Ann Trop Paediatr 1992; 12:55-66.

14. Touwen B. Neurological development in infancy. London: William Heineman Medical Books, 1976;76-7.

15. Yahya $S_{\text {, Roesin }} \mathrm{R}$. Indonesia-Implementation of the health-for-all strategy. In: WHO, Achieving health for all by the year 2000. Geneva: WHO, 1990;133-50.

16. Waterlow JC. The presentation and use of height and weight data for comparing the nutritional status of groups of children under tha age of 10 years. Bulletin WHO 1977; 55:489-98.

17. WHO. Measuring and monitoring growth and nutrition. In; WHO, Guidelines for training community health workers in nutrition; 2nd ed. Geneva: WHO, 1986;29-48. 
18. Torun B, Viteri FE, Protein-Energy Malnutrition. In; Tropical and Geographical Medicine. McGraw-Hill Book, New York: 1984;984-97.

19. Weisz JR, Sigman M, Weiss B, Mosk J. Parent reports of behavioral and emotional problems among children on Kenya, Thailand and The United States. Child Dev 1993; 64: 98-109. 